\title{
The Jurisprudence and Approaches of Constitutional Interpretation by the House of Federation in Ethiopia
}

\begin{abstract}
This article examines the jurisprudence of the Council of Constitutional Inquiry (CCI) and the House of Federation (HoF) in resolving constitutional disputes with a view to identifying the principles/approaches utilized in their decisions and its human rights implication. These organs are entrusted with the power to interpret the Constitution upon application by private parties or court referral of cases. The article also examines patterns in the judiciary's referral of cases for constitutional interpretation, and it discusses the methods and principles used by $\mathrm{CCI} / \mathrm{HoF}$ in constitutional interpretation. Although the $\mathrm{CCI} / \mathrm{HoF}$ has not expressly adopted distinct principles/approaches of constitutional interpretation, they can be inferred from the jurisprudence of the CCI and the HoF. I argue that there is inconsistent application of principles of constitutional interpretation. This is related with the incoherence observed in the constitutional interpretation of fundamental human rights recognized under the FDRE Constitution and ratified international human rights conventions. This shows that the $\mathrm{HoF}$-which is a political body- has failed to protect basic human rights through its decisions that involve politically sensitive cases. There is thus the need to develop and adopt rules of procedure and principles of constitutional interpretation that can ensure predictability, consistency and coherence in $\mathrm{HOF} / \mathrm{CCI}$ decisions towards the protection of human rights.
\end{abstract}

Anchinesh Shiferaw Mulu *

\section{Key terms}

Human rights $\cdot$ Constitutional interpretation $\cdot$ House of Federation $\cdot$ Council of Constitutional Inquiry

DOI http://dx.doi.org/10.4314/mlr.v13i3.4

This article is licensed under a Creative Commons Attribution-NonCommercial-

NoDerivs (CC BY-NC-ND)

Suggested citation:

Mulu, Anchinesh Shiferaw (2019), 'The Jurisprudence and Approaches of

Constitutional Interpretation by the House of Federation in Ethiopia', Mizan Law

Review, Vol. 13, No. 3, pp. 419-441

\footnotetext{
* Anchinesh Shiferaw Mulu (LLM (Pretoria University) and LLB (Addis Ababa University) is a PhD student and a Lecturer at the Center for Human Rights of Addis Ababa University. I am grateful to the two anonymous reviewers for their comments and suggestions which improved this article.Email: anchinesh.s@gmail.com ORCID: https://orcid.org/0000-0002-2190-8283
} 


\section{Introduction}

Ethiopia has opted for the Federal system of governance under the Federal Democratic Republic of Ethiopia Constitution (FDRE Constitution). ${ }^{1}$ The Constitution confers division of power between the federal and state governments. $^{2}$ It has also established the House of Federation (HoF) entrusted with the functions of constitutional interpretation and the adjudication of any constitutional dispute among members of the federations. ${ }^{3}$ According to the minutes of the Constitution, the HoF is vested with such power for two reasons. First, the framers of the Constitution considered the Constitution as a contract among nationalities. These premises determined the membership of the House of Federation which is composed of representatives of the various nationalities by considering them as the sole guardians of the Constitution who should be entrusted with the power to review the constitutionality of laws.

The second reason was that the framers wanted to avoid the 'tyranny of the judiciary' or 'judicial activism/adventurism' by empowering the judiciary with the power to interpret the Constitution. They seemed to have assumed that judicial review might give judges the discretion to use their own personal philosophies rather than the interest of nationalities in interpreting the Constitution. Because of such fear, the HoF was empowered to interpret the Constitution. ${ }^{4}$ In order to compensate the gaps in technical expertise among members of $\mathrm{HoF}$ in exercising constitutional interpretation, the FDRE Constitution established the CCI which consists of eleven members comprising the chief justice of the Federal Supreme Court, its deputy, six legal experts and three members from the HoF. ${ }^{5}$

The constitutional supremacy clause of the FDRE Constitution stipulates that any law, customary practices or a decision of an organ of the state or a public official should not contravene the Constitution. ${ }^{6}$ This clause is authoritative over the Federal and State governments. Federal and state governments are expected

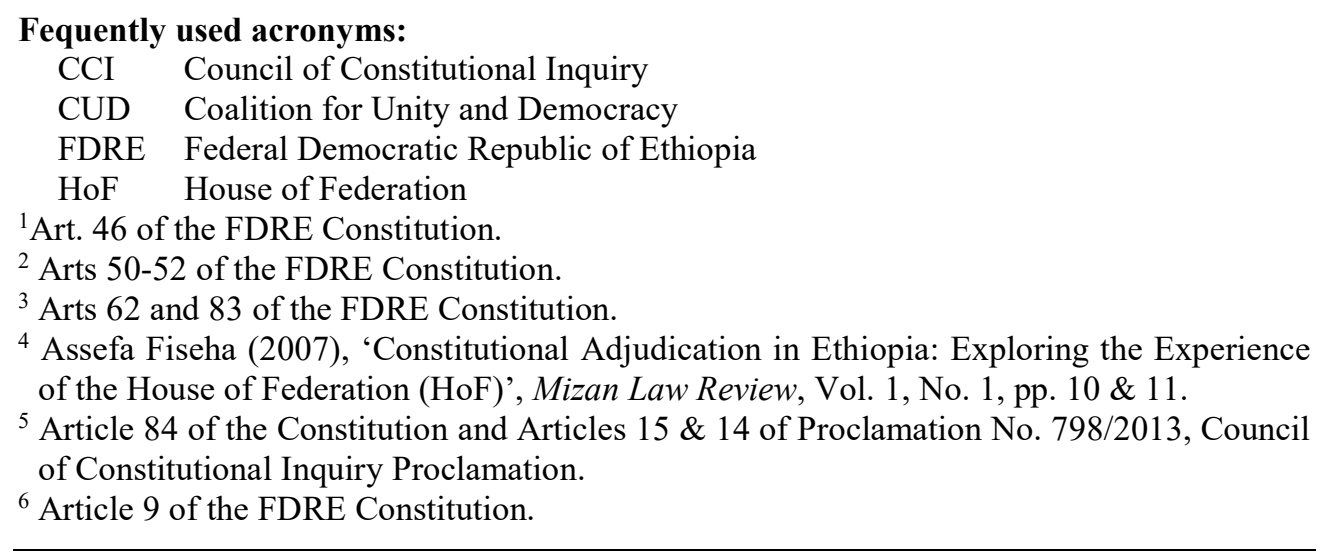


to enact laws in conformity with the Constitution. The supremacy clause of the Constitution is enforced by the HoF which can render any law that contravenes the Constitution ineffective. ${ }^{7}$ The $\mathrm{CCI} / \mathrm{HoF}$ exercises this power by entertaining any constitutional dispute that is referred to it by a court or an interested party.

While interpreting the Constitution to resolve any constitutional dispute, Proclamation No. 251/2001 (enacted to consolidate the HoF) authorizes the HoF to identify and implement principles of constitutional interpretation as it deems necessary. ${ }^{8}$ Although CCI was given such authority under Article 20(1) of the repealed Proc. No. 250/2001, it is repealed under Proc. 798/2013. However, both the $\mathrm{HoF}$ and $\mathrm{CCI}$ have not developed principles of constitutional interpretation. ${ }^{9}$ The CCI has now drafted rules of procedure which mainly deals with procedural issues such as standing, hearing procedures and cases admission procedures but not methods or principles of interpretation. ${ }^{10}$

The first section of this article discusses the legal grounds for court referral of cases. After a brief overview of originalism and non-originalism in constitutional interpretation (highlighted in Section 2), the third section discusses the principles applied by the HoF/CCI based on inference from their jurisprudence. The fourth section deals with the impact of the decisions of the $\mathrm{CCI} / \mathrm{HoF}$ on human rights.

\section{Constitutional Interpretation Powers of CCI and HoF}

The Ethiopian Constitution has centralized the power of constitutional interpretation and review of the constitutionality of laws to a single organ, i.e., the HoF. According to Article 83 (1) of the FDRE Constitution, "[a]ll constitutional disputes shall be decided by the House of Federation." The words 'all constitutional disputes' include "any constitutional issue, whether legislative, executive or judicial, as long as the final determination of the meaning of a constitutional provision is necessary". ${ }^{11}$ According to Article 84(1) of the FDRE Constitution, CCI investigates constitutional disputes and provides its recommendations to the HoF when there is a need for constitutional interpretation.

\footnotetext{
${ }^{7}$ Assefa, supra note 4, p. 5.

8 Art. 7 (1) of Proclamation No. 251/2001.

${ }^{9}$ Interview with Yadeta Gizaw and Rehel Berhanu, experts at the Secretariat Office of Council of Constitutional Inquiry conducted on April 30 and May 16, 2019 in their office.

${ }^{10}$ Interview with Rehel Berhanu, expert at the Secretariat Office of Council of Constitutional Inquiry conducted on May 16, 2019.

${ }^{11}$ Adem Kassie (2012), The Potential Role of Constitutional Review in the Realization of Human Rights in Ethiopia, Pretoria University (unpublished PhD dissertation) p. 75.
} 
Constitutional review can be initiated by government bodies, private parties or through judicial referral requesting $\mathrm{CCI}$ to review the constitutionality of the contested legislation, decision or conduct. $^{12} \mathrm{HoF}$ interprets the FDRE Constitution and review the constitutionality of laws including proclamations issued by the Federal or State legislative organs, regulations, directives, and international agreements ratified by Ethiopia. ${ }^{13}$ This has narrowed down the power of courts to review the constitutionality of any law including regulations and directives issued by the Council of Ministers and Ministers respectively. ${ }^{14}$

CCI provides technical support to the HoF by first investigating the case submitted to it for constitutional interpretation and providing its recommendations when there is prima facie case requiring constitutional interpretation or rejecting the case when there is no need for interpretation. In the latter case, the parties can appeal to the HoF against the decision of CCI. The HoF is at liberty to disregard the recommendations of CCI because of the advisory/recommendatory nature of the decision of the latter as it does not have the power to make final decisions. ${ }^{15}$

$\mathrm{CCI} / \mathrm{HoF}$ has increasingly been overloaded with cases. It has received 4,267 cases from its establishment until April 2019. Among these cases, it has reviewed 2,225 cases which constitute $52 \%$ of the cases submitted for constitutional review as indicated in the table below. About 2,152 cases have been rejected by the CCI. This constitutes $96.7 \%$ of the cases. It is only about $3.2 \%$ or 72 cases that have been decided while 2,042 cases constituting $47.8 \%$ of the cases submitted for review are pending before CCI.

Table 1:

The number of cases submitted and reviewed by HoF and CCI (until April 2019.)

\begin{tabular}{|l|l|c|}
\hline No. & Item & $\begin{array}{l}\text { No. of } \\
\text { cases }\end{array}$ \\
\hline 1. & Cases submitted to CCI & 4267 \\
2. & Cases reviewed by CCI & 2225 \\
3. & Cases decided by CCI & 72 \\
4. & Cases decided by HoF & 73 \\
\hline 5. & Reversed cases by HOF & 8 \\
\hline
\end{tabular}

Source: House of Federation and Council of Constitutional Inquiry

According to the experts at $\mathrm{CCI}$, the public tends to consider $\mathrm{CCI} / \mathrm{HoF}$ as an appellate body after cases are rejected by the Cassation Division of the Federal

12 Takele Soboka (2011), 'Judicial Referral of Constitutional Disputes in Ethiopia: From Practice to Theory', 19 African Journal of International and Constitutional Law, p. 104.

${ }^{13}$ Article 2 (2) of Proclamation No. 251/2001 consolidation of the House of the Federation and Definition of its Powers and Responsibilities.

${ }^{14}$ Assefa, supra note 4, p. 17.

${ }^{15}$ Article 5(2) of Proclamation No. 251/2001. See also Assefa, supra note 4, p. 14. 
Supreme Court. Most applicants seek constitutional interpretation on issues of fact or legal issues which do not require constitutional interpretation. A great number of cases $(96.7 \%)$ are thus rejected for lack of constitutional dispute or issues. ${ }^{16}$

Most of the applications for constitutional interpretation at the CCI are submitted by private parties. It is only six out of 72 cases reviewed by the CCI that are referred by courts until April $2019 .{ }^{17}$ The applications by private parties can be made on any ground and there are no requirements on the parties to frame the constitutional issues. The various private parties who applly for constitutional interpretation include individuals, political parties, and associations.

Various issues are involved in the cases submitted to CCI. The journal of the CCI which is published for the first time in 2018 contained 37 cases decided by CCI. The publication has classified the cases into 7 categories based on the rights that require constitutional interpretation. These categories include rights to property (17 cases), marriage and family related cases ( 2 cases), access to justice ( 7 cases), women's rights ( 4 cases), equality rights ( 2 cases), children's rights ( 2 cases), economic, social and cultural rights ( 2 cases), and supremacy of the constitution (one case). Large proportion of the cases brought to CCI involved land rights claims. ${ }^{18}$

When a case is referred by a court for constitutional interpretation, the court should demonstrate the triggering factors and frame the constitutional issues. The factors that can constitute grounds for referral of cases to $\mathrm{CCI} / \mathrm{HoF}$ from courts can be observed from the patterns highlighted below.

\subsection{Triggering factors for constitutional interpretation}

During application by 'interested party', cases usually involve abstract review of constitutionality while constitutional interpretation is applied on concrete cases/issues that are examined by CCI based on referral from courts. In case of

\footnotetext{
${ }^{16}$ Interview, Supra note 10.

${ }^{17}$ The cases are Federal Ethics \& Anti-Corruption Commission (FEACC) vs. Melaku et al, File no. 141356; Coalition for Unity and Democracy v. Prime Minister Meles Zenawi Asres, Fed. First Instance Ct., Lideta Div., File No. 54024 (Decision of 3 June 2005) (26 Ginbot 1997 E.C.); Ethiopian Revenue and Custom Authority vs. Ato Eyob Zewdie, Federal First Instance Court, File No. 218283, 2009 E.C; Prosecutor v. Mohadi Ali, Ahmed Adem and Ali Delbtu, Council of Constitutional Inquiry, File No. 2356/2009 (29 Hamle 2009 E.C.); Civil Servants Administrative Tribunal vs. FDRE Revenues and Customs Authority and its Moyale Branch Office, File No. 2189/09 (Tir 8, 2011 E.C. (2019))

${ }^{18}$ Secretariat of Council of Constitutional Inquiry (2018), Recommendations of Council of

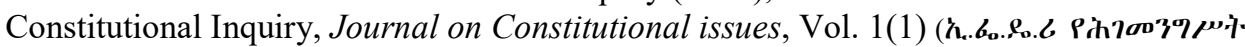

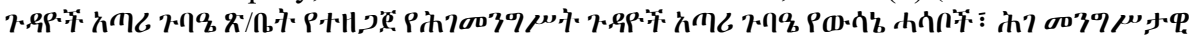

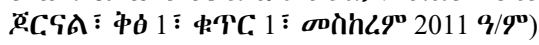


court referral, the court refers a case to $\mathrm{CCI}$ (while the case is pending before the court) on its own motion or upon the request of a party to the case. In both cases, the CCI needs to ascertain the need for constitutional interpretation. ${ }^{19}$

The court on its part needs to show that it is unable to adjudicate the case applying all techniques of interpretation. It should demonstrate that the referral to $\mathrm{CCI}$ is its last resort after having tried to apply all interpretative solutions in conformity with the Constitution. ${ }^{20}$ When a court refers a case to CCI, it is expected to send the legal issue contested not the factual issue. Thus, CCI does not make a decision on the facts of the case but rather reviews the constitutionality of legislation that is contested or provide constitutional interpretation. ${ }^{21}$ According to Takele Soboka, "CCI and the HoF are not adjudicatory bodies" and they exercise "quasi-judicial powers constitutionally ceded to them and exercisable exceptionally when the constitutionality of a law is at issue". ${ }^{22}$ This is in line with the argument that the judiciary has exclusive adjudicatory power. The Constitution also envisages the case to be remanded to the court after the decision of the HoF so that the court can decide on the merits of the case.

In practice, courts frame the constitutional issues based on the constitutional provisions in most cases. ${ }^{23}$ However, in the Coalition for Unity and Democracy

${ }^{19}$ Takele, supra note 12, p. 112.

${ }^{20}$ Id., p. 114.

${ }^{21}$ Assefa, supra note. 4, p. 29.

${ }^{22}$ Takele, supra note 12, p. 117.

${ }^{23}$ In Melaku's case the court framed the issue as follows in referring the case to CCI based on Arts. 83(1) and 84 (2) of the Constitution: The court requested the CCI to look into:

- Whether Art 8 (1) of Proc. No. 25/1996 (Proclamation establishing the Federal Courts) and Art. 7 (1) of Proc. No. 434/2005 (Revised Proclamation providing for Special Procedure and Rules of Evidence on Anti-Corruption) is contrary to Articles 20 (6), 25, 10 and 13 (1) of the FDRE Constitution.

- Whether it is the Federal High Court or federal Supreme Court that has the material jurisdiction to entertain the case?

See Federal Ethics \& Anti-Corruption Commission (FEACC) v. Melaku et al; File No. 141356. In a terrorism case involving three accused persons, the court framed the constitutional issue as follow in referring the case to CCI:

- Whether witness protection through withholding of names and identity of witnesses under Article 32 (1) of Proc. No. 652/2009 and Article $4(\mathrm{H})$ \& (J) is constitutional in light of Article 20 (4) of the FDRE Constitution

See Prosecutor vs. Mohadi Ali, Ahmed Adem and Ali Delbtu, Federal High Court; File No. 192735 (14/9/2009 E.C)

In a case referred to the CCI by the Civil Servant Tribunals, the Tribunal requested $\mathrm{CCI}$ to evaluate the constitutionality of the provision of the Regulation which prohibits the Judiciary from reviewing the decision of the Director General of Ethiopian Revenues and Custom Authority to dismiss an employee in light of Art. 37 (1) and 20(4) of the FDRE 
(CUD) case $^{24}$-which challenged the issuance of Directive by the then Prime Minister banning outdoor assemblies and demonstrations in Addis Ababa and its vicinities during the a May 2005 elections- the court framed a question of factual application to the case rather than a constitutional issue. The court did not attempt to contest the constitutionality of the law invoked by the parties. It rather framed the issue which examined whether it 'was the directive of the Prime Minister [which banned outdoor meetings and demonstrations for one month] in contravention of the Constitution?' This issue only requires factual application of the law. The court was left with no other factual determination after the CCI decided answering the issue framed. ${ }^{25}$ According to Sisay,

the Court erred in failing to refer the case to the Council of Constitutional Inquiry (the Council) without considering the provisions of Proclamation No.

3/1991 and without first deciding on whether there was lack of clarity of the Constitution; and the Council failed to decide on whether there was 'constitutional dispute' giving rise to its jurisdiction. ${ }^{26}$

Similarly, Takele Soboka is of the view that "the Court not only failed to specify a provision that needed interpretation but also failed to frame question of law while the Council went beyond its power to apply the Constitution to factual situation". ${ }^{27}$ But in other cases referred by courts, courts properly made reference to the specific provisions that need interpretation or determination of constitutionality. ${ }^{28}$

In Coalition for Unity and Democracy (CUD), the CCI should have made its decision in abstract. However, it went beyond its power and applied the law to the facts. The Council relied on the constitutional provision providing state of emergency rather than relying on the explicit provision of the Constitution stipulating the power of the Prime Minister. It further determined whether the factual circumstances warrant the state of emergency rather than determining whether the Prime Minister has the power to issue a state of emergency. ${ }^{29}$ In its ruling, the CCI held that the factual evaluation of the ban demonstrates that it

Constitution and Article 14(3)(b)\&(e) of the Covenant on Civil and Political Rights. See Prosecutor vs. Mohadi Ali, Ahmed Adem and Ali Delbtu, Council of Constitutional Inquiry, File No. 2356/2009 (29 Hamle 2009 E.C.)

${ }^{24}$ Coalition for Unity and Democracy vs. Prime Minister Meles Zenawi Asres, Fed. First Instance Ct., Lideta Div., File No. 54024 (Decision of 3 June 2005) (26 Ginbot 1997 E.C.)

${ }^{25}$ Takele, supra note 12, p. 118.

${ }^{26}$ Sisay Alemahu (2008), "The Justiciability of Human Rights in the Federal Democratic Republic of Ethiopia", 8 African Human Rights Law Journal. p. 273.

${ }^{27}$ Takele, supra note 12, p. 100.

${ }^{28}$ Supra note 23.

${ }^{29}$ Adem, supra note 11, pp. 87 and 211. 
was necessary and Prime Minister's declaration of the ban on demonstration and assembly was constitutional. ${ }^{30}$

Similarly, in a terrorism case referred to the CCI by the Federal High Court ${ }^{31}$, CCI applied the law to the facts of the case. ${ }^{32}$ It argued that the court should have not referred the constitutional issue. The court framed the issue in this case as to "whether witness protection through withholding of names and identity of witnesses under Article 32(1) of Proclamation No. 652/2009 (Anti-terrorism Proclamation) and Article 4(H) \& (J) of Proclamation No. 699/2010 (which should have been stated as Proclamation No. 699/2011 in the Negarit Gazeta) is constitutional in light of Article 20 (4) of the FDRE Constitution". However, the CCI pointed that the determination of this issue is not relevant to the case which is pending before the court. Here, it made analysis of the facts of the case. This should have been left for the judiciary to decide. It held that Article 32(1) of Proclamation No. 652/2009 and Article 4(H) \& (J) of Proclamation No. 699/2010 are constitutional in light of Article 20(4) of the FDRE Constitution. However, the CCI should have used this opportunity to review the Constitutionality of the Anti-terrorism Proclamation in light of the human rights provisions of the Constitution.

\subsection{Grounds for court referral}

When courts refer a case to CCI, they do not have to establish that there is a prima facie case of unconstitutionality. However, they have to review the case and believe in the need for constitutional interpretation. According to Article 21(2) of Proclamation No. 251/2001, the Court handling the case "shall submit it to the CCI only if it believes that there is a need for constitutional interpretation in deciding the case". Although the court refers to issues of fact and law, the CCI entertains cases in abstract by interpreting the Constitution without having to go into the merits of the case. ${ }^{33}$

In other jurisdictions, the principle of avoidance is applied by courts more often. Mostly, courts tend to indirectly apply the Constitution. This means that "where it is possible to decide any case, civil or criminal, without reaching a

${ }^{30}$ Takele, supra note 12, pp. 119-220.

${ }^{31}$ Prosecutor vs. Mohadi Ali, Ahmed Adem and Ali Delbtu, Federal High Court, File No. 192735 (14/9/2009 E.C)

32 Prosecutor vs. Mohadi Ali, Ahmed Adem and Ali Delbtu, Council of Constitutional Inquiry, File No. 2356/2009 (29 Hamle 2009 E.C.)

${ }^{33}$ Adem, supra note 11, p. 77; In case of the diffuse system which is applied in the USA, the supreme court provides interpretation of the constitution on concrete case before it while in case of concentrated system a separate organ which can be Constitutional court or a separate special body interprets the constitution on an abstract case. See also Takele, supra note 12, p. 104. 
constitutional issue that is the course which should be followed". Courts mostly rely on ordinarily legislation to avoid referring the case for constitutional interpretation. ${ }^{34}$ However, the trend in Ethiopia shows that courts easily relinquish their jurisdiction over constitutional disputes and refer a case to the $\mathrm{CCI} / \mathrm{HoF} .{ }^{35}$ This is mainly related with two factors highlighted below.

\subsubsection{The tendency to avoid issues that involve the application of a constitutional provision}

The first factor that has created the tendency of courts to relinquish their jurisdiction over constitutional disputes is the view by courts that any issue that involves interpretation and application of constitutional provision requires referral of the case to the $\mathrm{CCI} / \mathrm{HoF}$. This emanates from Article 83(1) of the FDRE Constitution which provides that 'all constitutional disputes' shall be decided by the HoF.$^{36}$ For instance, in one of the cases which was referred to the CCI by the Federal First Instance Court $^{37}$ to determine whether the favourable provision of Proclamation No. 983/2008 should be applicable to the applicant who is serving his sentence based on the provisions of Proclamation No. 285/1994, the court framed the issue based on the contradictory meaning given to 'conviction' under the Amharic and English versions of Article 22(2) of the FDRE Constitution.

The Amharic version provides that a sentenced person can benefit from favourable punishment by applying it retroactively. The court in this case could have directly applied the constitutional provision which explicitly provides that the Amharic version prevails in case of contradiction between the Amharic and English versions of the provisions of FDRE Constitution. ${ }^{38}$ In the terrorism case mentioned above which was referred to the CCI, the Federal High Court unduly relinquished its power by referring the case involving a constitutional provision to $\mathrm{CCI} .{ }^{39}$ The case involved three individuals accused of terrorism based on the previous anti-terrorism proclamation (Proclamation No. 652/2009). They argued that they have not received the specific name of the witnesses to the case and places where the crime was allegedly committed. They argued that these prevented them to prepare their defence being fully aware of the evidence presented against them. It was noted that Article 20(4) of the FDRE Constitution

\footnotetext{
${ }^{34}$ Takele, supra note 12, p. 107.

${ }^{35}$ Id., p. 100.

${ }^{36}$ Ibid.

${ }^{37}$ Ethiopian Revenue and Custom Authority v. Eyob Zewdie, Federal First Instance Court, File No. 218283, 2009 E.C.

${ }^{38}$ Article 106 of the FDRE Constitution provides that the Amharic version of the Constitution will have a final legal authority.

${ }^{39}$ Prosecutor vs. Mohadi Ali, Ahmed Adem and Ali Delbtu, Federal High Court, file no. 192735 (14/9/2009 E.C)
} 
guarantees the right (of accused persons) to full access to any evidence presented against them. The court referred the case to the CCI to determine whether protection of witness under Article 32(1) of Proclamation No. $652 / 2009^{40}$ and Article $4(\mathrm{H}) \&(\mathrm{~J})$ of Proc. No. 699/2010 is constitutional in light of Article 20(4) of the FDRE Constitution. However, the court could have applied the constitutional provision directly. As argued by Sisay:

The Ethiopian Constitution enshrines provisions specific enough to be applied by courts (examples are rights of persons under arrest and rights of the accused under Articles 19 and 20 respectively). Moreover, ... there are constitutional rights which do not have a perfect substitute in ordinary legislation. An example is the right of accused persons to 'full access to any evidence presented against them' under Article 21(4) of the Constitution. Courts cannot totally avoid referring to constitutional rights, especially in the latter cases. ${ }^{41}$

Courts should abstain from any referral of cases at all times merely because a constitutional provision is invoked. However, the FDRE Constitution does not have a limitation clause which guides the determination of the constitutionality of a limitation, and thus courts might face difficulty in applying constitutional provisions which involve limitation clauses. In such cases, courts should refer the case to CCI to get an interpretation on constitutionality of any limitation on the constitutional rights.

\subsubsection{Avoidance of politically sensitive issues}

The second reason for the tendency of courts to relinquish their power in favour of CCI is that courts want to avoid politically sensitive issues. When courts are faced with politically sensitive issues, they tend to refer the case to $\mathrm{CCI} / \mathrm{HoF}$ which is more of a political organ. ${ }^{42}$ This was what was pursued by the court in the CUD case and Melaku's case. ${ }^{43}$ In the CUD case which involved the banning of demonstration and assembly by the then Prime Minister in 2005, the court referred the case to the CCI despite the objection of the applicant. In this case, CUD brought the case before the Federal First Instance Court by relying on Proclamation No. 3/1991 that provides for procedures of demonstration and public political meetings. CUD tried to base its argument on the Proclamation to

\footnotetext{
${ }^{40}$ Article 32 of Proclamation No. 652/2009 provides that the court may allow the withholding of names and identity of witnesses for the purpose of witness protection.

${ }^{41}$ Sisay, supra note 25. p. 284.

${ }^{42}$ Takele, supra note 12, p. 101.

${ }^{43}$ Federal Ethics \& Anti-Corruption Commission (FEACC) V. Melaku et al, file no. 141356, in House of Federation, Journal of Constitutional Decisions, 2009 E.C. (2017), Vol. 2 (2), p. 7-30 and Coalition for Unity and Democracy v. Prime Minister Meles Zenawi Asres, Fed. First Instance Ct., Lideta Div., File No. 54024 (Decision of 3 June 2005) (26 Ginbot 1997 E.C.);
} 
avoid the referral of the case to a political organ (CCI) if constitutional provision is cited as the basis of its argument. However, the court referred the case to CCI against the open opposition of the complainant. This shows the tendency of courts to avoid rendering decisions on politically sensitive cases.

Similarly, in Melaku's case, the court on its own initiation referred the case to the CCI. The case involved a General Director of the Ethiopian Revenues and Customs Authority who has been accused (before the Federal High Court) based on Articles 8(1) Proclamation No. 25/1996 and Article 7 (1) of Proclamation No. 434/2005. The proclamations required Ministers or state officials of the Federal government to be subject to the jurisdiction of the Federal Supreme Court for crimes in connection with their official positions/responsibilities. Thus, the court requested CCI to determine constitutionality of the proclamations in light of the right to appeal and equal protection before the law guaranteed under Articles 20(1) and 25 of the FDRE Constitution. The issue framed by the court was 'whether the adjudication of the case of Melaku Fanta who was Director General of Ethiopian Revenues and Customs Authority with a Minister portfolio before the Federal Supreme Court restricts his constitutional right to appeal'. The court requested this despite the fact that it could have applied the ordinary law. Even though on its face value, the judiciary's referral seemed to seek the protection of the accused person's constitutional right of appeal, the real reason behind the court referral was the judiciary's preference to defer political issues.

\section{Originalism and Non-originalism in Constitutional Interpretation}

There are various principles/theories on constitutional interpretation that have acquired recognition in various countries. In the USA and other countries, the following theories and principles were used by the federal and state courts to interpret the Constitution.

\subsection{The theory of originalism}

This theory is invoked by US Federal and State courts. ${ }^{44}$ Originalism theory is defined as both original-intent originalism and original-public-meaning originalism. ${ }^{45}$ However, the theory is criticized for disregarding constitutional interpretation based on contemporary meanings, values or understandings of a constitution. ${ }^{46}$

\footnotetext{
${ }^{44}$ Jeremy M. Christiansen (2017), 'Orginalism: The Primary Canon of State Constitutional Interpretation', the Georgetown Journal of Law and Public Policy, vol. 15, p. 344.

${ }^{45}$ Id., p. 348.

${ }^{46}$ Jeffrey Goldsworthy (2009), 'Constitutional Interpretation: Originalism', Philosophy Compass, Vol. 4, Issue 4, p. 689.
} 
a) Original intent- is considered as the primary canon of interpretation and gives primacy "to the intent and purpose of the framers of the constitutional provision and of the people who adopted it". ${ }^{47}$

b) Original public-meaning (Textual interpretation)- refers to constitutional interpretation conducted according to the original meaning of the constitution. ${ }^{48}$ Textualist approach as opposed to the intentionalist paradigm focus on "the spirit and intent of [the] framers, as indicated by [the documents'] language". ${ }^{49}$ According to textual interpretation, constitutional interpretation should be "in light of ordinary language, the circumstances attending its formation, and the construction placed upon it. ..."

\subsection{Non-originalism in constitutional interpretation}

Non-originalism is the second type of constitutional interpretation which takes into account contemporary contexts and understanding of a constitution. It includes the following.

a) Living constitutionalism: It started to be applied since early twentieth century in the USA. The Constitution is considered as living document with changing terminologies with the change in the time and circumstances. The Constitution is expected to meet the demands of a progressive society and embrace extensive relations. ${ }^{51}$ Jack M. Balkin argued that this theory should not be considered as theory of constitutional interpretation, but should rather be regarded as constitutional construction. According to Balkin, constitutional construction is a "process of building institutions of government and implementing and applying the constitutional text and its underlining principles". He also contends that the theory is applicable to citizens, not to constitutional judges. This theory explains how constitutional change occurs in the interaction between the political branches and courts. ${ }^{52}$

b) Lockstep interpretation: It means 'interpreting a state provision to mean the same thing the U.S. Supreme Court has interpreted an analogous federal provision' ${ }^{53}$ This is also similar to pragmatist approach which gives more weight to judicial precedent.

c) Totality of the circumstances approach or "Motley Constellation"/Factor framework: According to this interpretative framework, history, and structure

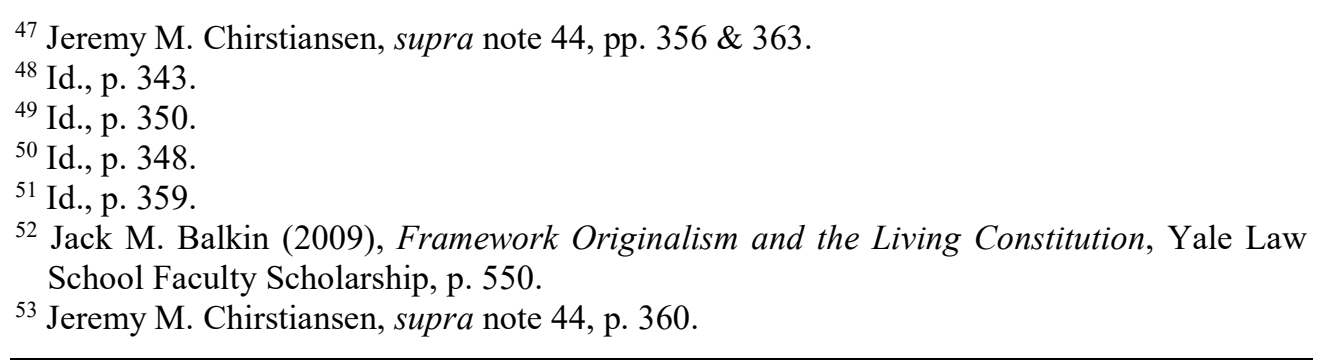


of the constitution, other factors based on "contemporary understandings of applicable economic and sociological norms" are also important factors to be considered in constitutional interpretation in addition to the text of the constitution. $^{54}$

d) Natural Law theory provides that a higher moral law prevails over the constitution and the constitution should be interpreted according to these rules. ${ }^{55}$

Original meaning originalism and living constitutionalism are taken as contradictory. However, Jack M. Balkin proposed a method that combines the two together which he called 'method of text and principle'. This method allows the application of text and principles based on the needs of the time. This requires building political institutions, passing legislation, and creating judicial and non-judicial precedents. ${ }^{56}$

\section{Principles and Approaches of Interpretation in HoF Decisions}

The FDRE Constitution does not provide principles/methods of constitutional interpretation except for the interpretation of provisions on fundamental rights and freedoms which should be interpreted in conformity with the principles of the Universal Declaration of Human Rights (UDHR), international covenants on human rights and international instruments adopted by the Ethiopia. ${ }^{57}$ The preamble of the Constitution, the principles enshrined under Articles 8-12 of the FDRE Constitution ${ }^{58}$ and the prevalence of the Amharic version of the Constitution over the English version (in case of ambiguity of its provisions) can be considered as statutory interpretation guides. ${ }^{59}$

Both the CCI and HoF do not have detail rules on approaches or methods of interpretation to be applied in the cases before them. ${ }^{60}$ Their approaches can only be inferred from the jurisprudence of their decisions. In practice, $\mathrm{CCI} / \mathrm{HoF}$

${ }^{54}$ Id., p. $358 \& 362$.

${ }^{55}$ R. Randall Kelso (1994), 'Styles of Constitutional Interpretation and the Four Main Approaches to Constitutional Interpretation in American Legal History', Valparaiso University Law Review, Vol. 29, No. 1, p. 159. See also Michael S. Moore (2001), 'Justifying the Natural Law Theory of Constitutional Interpretation', Fordham Law Review. Vol. 69, No. 5, p. 2088.

56 Jack M. Balkin, (2009), supra note 52.

${ }^{57}$ Article 13 (2) of the FDRE Constitution and Article 7 (2) of Proclamation No. 251/2001.

${ }^{58}$ These principles include popular sovereignty, supremacy of the constitution, respect for fundamental rights and freedoms, secularism, government transparency and accountability.

${ }^{59}$ Mustefa Nasser (2018), Methods of Constitutional Interpretation in Constitutional Dispute Settlement in Ethiopia, (unpublished LL.M thesis), School of Law, Addis Ababa University, p. 18-20.

${ }^{60}$ Id., 59, p. 30. 
has applied various approaches in interpreting the Constitution. It is important to note that a single decision may apply one or more methods or principles of interpretation. The cases highlighted below indicate the approach pursued by $\mathrm{CCI} / \mathrm{HoF}$ to interpret the FDRE Constitution.

\subsection{Textual interpretation}

The textual interpretation model endorses that the interpretation of a constitution should focus on what the law basically asserts through the literal and technical meaning of its provisions. ${ }^{61}$ It asserts that the words of a constitution are to be taken at face value and given ordinary and accepted meaning. ${ }^{62}$

The HoF has mostly applied textual interpretation in interpreting the FDRE Constitution. ${ }^{63}$ Most of the cases on land rights issues decided by the CCI and HoF apply textual interpretation in addition to considering policy issues behind those provisions. For instance, in the cases of Aliye Dawe vs. Mumad Adem, Hasay Doye vs. Tinsaye Kutale et. al, Banchamlak Dersolgn vs. Abebaw Mola, Kelebe Tesfa vs. Ayelegn Derbew, and Muyedin Yunis vs. Nassi Aliye et. al, the HoF relied on the literal application of Article 40(3) of the FDRE Constitution which provides that "[1] and is the common property of the Nations, Nationalities and Peoples of Ethiopia and shall not be subject to sale or to other means of exchange." In these cases, the court's decision was found to be contrary to this provision of the Constitution as it relied on contractual interpretation. ${ }^{64}$

In most cases, the $\mathrm{CCI}$ and $\mathrm{HoF}$ invalidated various private dealings on land that resulted in the eviction of the original holders of the land. In the case of Ato Ketefo Gebreeyes and W/ro Denekenesh Jima ${ }^{65}$, CCI invalidated donation of land given by applicants who have no other means of livelihood and they donated the land to the respondents believing that the latter will support them in

${ }^{61}$ Brandon J. Murrill (2018), Modes of Constitutional Interpretation. Congressional Research Service Report, p. 5.

${ }^{62}$ Craug R. Ducat (2009), Constitutional Interpretation, 9th Edition, Wadsworth, Cengage Learning, p.77.

63 Interview with Ato Yawekal Bekele, Director of the Directorate on Constitutional Interpretation and Identify Issues, House of Federation, conducted on 6 June 2019.

${ }^{64}$ Aliya Dawe v. Mumad Adem case is about the sale of land which the applicant requested to be returned. The Court accepted the validity of the sale. However, the HoF nullified the sale of the land. In the case of Hasay Doye vs. Tinsaye Kutale et.al, the HoF nullified a court decision that validated a sale of rural land based on article 40 (3) of the FDRE Constitution. The other cases (Banchamlak Dersolgn vs. Abebaw Mola, Kelebe Tesfa vs. Ayelegn Derbew, and MuyedinYunis vs. Nazi Aliye et. Al) also involved the sale of rural land which was held unconstitutional based on the provision of the Constitution prohibiting sale of land. See Mustefa, supra note 59, p. 29-30.

${ }^{65}$ Ato Kitifo Gebreyes and W/ro Deneknesh Jimma vs. Besufikade Ayele, 2009 E.C (2017), File No. 1663/08 in supra note 18, pp. 14-16. 
old age. They also argued that they are illiterate and did not understand the contract of donation upon signing. The CCI invalidated the agreement based on Article 40(4) of the Constitution which provides that Ethiopian peasants have the right to be protected from any eviction from their possession of rural land.

Similarly, in W/ro Kassaye Eshete vs. W/ro Askale Zemedkun, there were issues which involved division of rural land acquired before marriage. The CCI applied a constitutional provision that protects peasants from eviction and stated that the wife who has contributed through undertaking various developmental activities on the land during marriage should benefit from the equal division of the land upon divorce. The decision noted that the wife does not have any other land of her own and stated that she should get equal division from the land although the land was acquired by the husband before marriage and registered in his name by taking cognizance of women's lack of access to land. ${ }^{66}$

The CCI here had a policy consideration of availing fair access to land to women rather than application of textual interpretation. However, the HoF stated that according to the Amhara Regional State Proclamation on Rural Land, the land acquired before marriage and registered only in the husband's name is considered as personal property and cannot be subject to equal division among the spouses upon divorce. ${ }^{67}$ This has a bad implication on women's right to access, use and administer land. The facts on the ground show that women have a limited access to land as a result of cultural practices limiting women's access to land. Since land is owned by the state and the people, it should not be considered as personal property and should be subjected to equal division upon divorce when one of the spouses do not have any other land. This line of interpretation clearly departs from literal interpretation, and the HoF should have accordingly considered the rights of peasants to be protected from any eviction as it did in other decisions.

Contrary to their decision in W/ro Kassaye Eshete vs. W/ro Askale Zemedkun, in the case of W/ro Halima Mohamed vs. Ato Adem Abdi, both CCI and HoF stated that a husband who inherited his deceased brother's wife should not get equal division of the land which the wife jointly acquired during her previous marriage. The CCI stated that since the husband has another land acquired through succession in his second marriage, the land from which he claimed his share should be considered as personal property. It also argued based on the provision of the Constitution that protects women's rights. In its reasoning, it provided that allowing equal sharing of the land to the second husband will

\footnotetext{
${ }^{66}$ W/ro Kassaye Eshete vs. W/ro Askale Zemedkun (guardian of TsehayeTameri), September, 2011 E.C (2018), FDRE House of Federation $4^{\text {th }}$ year ordinary Meeting, p. 3 available on $<$ http://www.hofethiopia.gov.et/web/guest/decisions-documents//document/preview/29272/29114>. Accessed on 1 June 2019.

${ }^{67}$ W/ro Kassaye Eshete vs. W/ro Askale Zemedkun, Id., p. 4.
} 
promote bigamy and the practice of widow inheritance and also deprives the children born out of the previous marriage their inheritance rights contrary to the best interest of the child principle enshrined under the Constitution. ${ }^{68}$ The HoF endorsed the reasoning of $\mathrm{CCI}$ and decided that the equal division of the land which was acquired during previous marriage will deprive the woman from her right to access, administer and control land and also affects the best interest of the children. ${ }^{69}$ This decision is not in conformity with the decision in W/ro Kassaye Eshete vs. W/ro Askale Zemedkun discussed above.

In another case referred by the Federal First Instance Court, ${ }^{70}$ the CCI had to determine whether the favourable sentencing provision of Proclamation No. $983 / 2008$ should be applicable to the applicant, -who is serving his sentence based on the provisions of Proclamation No. 285/1994. The CCI applied textual interpretation in addition to giving consideration to the 'spirit' of the law. The Court that referred the case framed the issue based on the contradictory meaning given to 'conviction' under the Amharic and English versions. According to the Amharic version a sentenced person can benefit from favourable punishment by applying it retroactively while the English version provides that it is applicable to accused and convicted persons.

The existing law does not provide any procedure for a sentence to be reviewed by a court when a favourable law is enacted. Proclamation No. 983/2008 introduced a lower sentence of 3 to 15 years while 10-15 years was imposed in the previous proclamation (Proclamation No. 285/1994) for a crime related to VAT fraud. The CCI analysed whether the beneficiaries from the favourable applicable punishment should be accused/convicted defendants or persons who are sentenced. CCI inferred from Article 22(2) of the FDRE Constitution that a favourable provision under a new law is applicable to an accused or convicted person. Here, CCI relied on the meaning of the text of the Constitution which refers to the convicted person (which in this case referred to persons who are found guilty and awaiting the decision on their sentence). CCI noted that the spirit of the Constitution applies to persons who are convicted (but not yet sentenced) but not to persons who are already sentenced. CCI in this case rejected the case stating that there is no need for constitutional interpretation since the Constitution can be applied without any interpretation. However, the reliance of the CCI on the text of the English version of the

${ }^{68} \mathrm{~W} /$ ro Halima Mohamed vs. Ato Adem Abdi; File No. 713/04 in House of Federation, Journal of Constitutional Decisions, 2009 E.C., Vol. 2 (2), p. 64.

${ }^{69}$ Id., p. 68-69.

${ }^{70}$ File No. 2321/09; Date of decision: 14/10/2009 Ethiopian calendar (2017). The case was first entertained at the Federal First Instance Court between Ethiopian Revenues and Customs Authority (represented by its Prosecutor) vs. Ato Eyob Zewde, File no. 218283, Ginbot 23, 2009, Ethiopian Calendar. (Copy of the decision is on file with author) 
Constitution without considering the contradictory provisions of the Amharic versions resulted in the rejection of the case. The CCI should have considered the constitutional principle which provides that the Amharic version of the constitution would have the final authority. ${ }^{71}$

Textual interpretation has also been applied in cases that involved the determination of the 'best interest of the child' ${ }^{72}$ In these cases, the CCI/HoF applied the provision of the Constitution which requires all actions concerning children undertaken by public and private welfare institutions, courts of law, administrative authorities or legislative bodies to take the best interest of the child as primary consideration. ${ }^{73}$

The above analysis of the jurisprudence of the $\mathrm{CCI} / \mathrm{HoF}$ demonstrates that both institutions frequently relied on the principle of textual interpretation which in some cases has resulted in wrong conclusions. The literal meaning of the text of a Constitution may not, at times, result in the protection of individual rights unless it is interpreted in conjunction with the spirit of the Constitution or other human rights provisions of the Constitution.

\subsection{Harmonious construction (right balancing analysis)}

Harmonious construction is an approach that provides that "the constitutional provision should not be construed in isolation from all other parts of the Constitution, but should be construed as to harmonize with those other parts". ${ }^{74}$ Accordingly, a constitutional provision "should be given a meaning and an application which does not lead to conflict with other articles and which confirms with the Constitution's general scheme". ${ }^{75}$

The HoF applied this approach in its decision on the right to vote and be elected in Benshangul. ${ }^{76}$ The case involved the prohibition of candidates from Amhara, Oromo and Tigray nationalities in Benshangul from participating in the 2000 elections for the Regional Council. The prohibition by the National Election Board of Ethiopia (NEBE) was based on the inability of candidates to speak one of the five local languages i.e., Berta, Gumuz, Shinasha, Komo and Mao. The Amharas, Oromos and Tigray were resettled in Benishangul during

\footnotetext{
${ }^{71}$ Article 106 of the FDRE Constitution.

72 See W/ro Halima Mohamed vs. Ato Adem Abdi, File No. 713/04 in Journal of Constitutional Decisions, 2009 E.C, Vol. 2(2), pp. 58-69; Ato Birhanu Regassa Urgi v. Meskerm Mitiku and Emahoy G/Eyesus (Surafeal Zewdu's mother), supra 18, pp. 137-142.

${ }^{73}$ Article 36 (2) of the FDRE Constitution.

${ }^{74}$ Rajashree J Jawale, Principles of Constitutional Interpretation available on https://www.slideshare.net/sundarsasane/principles-of-constitutional-interpretation-of-list (accessed on 15 May 2019)

${ }^{75}$ Ibid.

${ }^{76}$ Decision on right to vote and be Elected in Benshangul (Benshangul case) in House of Federations, Journal of Constitutional Decisions, 2000 E.C. (2008), Vol. 1 (1), p. 14-34
} 
Derg's resettlement programmes, and they constituted 47 percent of the population of the region. ${ }^{77}$ The CCI in its majority vote decided that the prohibition is against the constitutional provision that provides for the right to be elected, and decided that the decision of the NEBE is unconstitutional.

However, the minority members of CCI noted that CCI should consider not only the specific provision but also look into the whole Constitution which guarantees the right to self-determination of nations, nationalities and peoples. It noted that there is a need to balance the right to be elected and the rights of nationalities. It stated there is no discrimination on the basis of language thereby considering that decision of NEBE as constitutional. Based on this CCI minority decision, the HoF decided that a candidate needs to know the working regional language but not the local language. However, NEBE's decision requiring the candidates to speak the local language was found unconstitutional. The constitutional interpretation applied by the majority is textual reading while the minority decision not only made textual reading of specific provisions of the Constitution, but also referred to the spirit of the Constitution which aims to balance individual rights and rights of nationalities.

The same principle is applied in the case of Ato Wesen Alemu et. al vs. The Amhara National Regional State (ANRS) Justice Professionals Training Institute. The case involved denial of visually impaired experts in law from becoming a judge. The HoF considered such denial as a violation of Articles 25 and 41(2) of the FDRE Constitution, Proclamation No. 676/2010 and the International Convention on the Rights of Persons with Disabilities. ${ }^{78}$ In this case, the HoF looked into the text of the Constitution and referred to the whole constitutional text. This decision can be considered as one of the decisions of the HoF which is pro-human rights. In general, harmonious construction -which would have resulted in fair decisions in various cases- is not applied by $\mathrm{CCI} / \mathrm{HoF}$ as extensively as textual interpretation.

\subsection{Interpretation based on international human rights instruments}

This interpretation is applied by referring to international human rights instruments ratified by Ethiopia. In Ato Melaku Fenta's case, ${ }^{79}$ the CCI and HoF invoked international human rights instruments to strengthen thier analysis on the right to appeal. They also made reference to the purpose of the law to determine whether Melaku's right to appeal is affected by the adjudication of his case by the Federal Supreme Court. $\mathrm{CCI} / \mathrm{HoF}$ stated that Proclamation No.

\footnotetext{
${ }^{77}$ Assefa, supra note 4, p. 23.

${ }^{78}$ Mustefa, supra note 59, p. 36.

${ }^{79}$ Federal Ethics \& Anti-Corruption Commission (FEACC) vs. Ato Melaku et al, File No. 141356, in House of Federation, Journal of Constitutional Decisions, 2009 E.C. (2017), Vol. 2 (2),p. 7-30.
} 
25/1996 which requires government officials to be tried by the Federal Supreme Court restrains their right to appeal and, in effect, violates equality before the law based on international human rights instruments such as the International Covenant on Civil and Political Rights (ICCPR) and African Charter on Human and peoples' Rights (ACHPR).

The CCI/HoF stated that the right to appeal is one of the rights recognized under the FDRE Constitution. The decison also noted that the denial of the right to appeal affects the chance to correct error in decisions which goes against the principle of fairness. It underlined that appeal is instrumental to ensure uniformity, predictability of decisions and accountability of judges. Furthermore, $\mathrm{CCI} / \mathrm{HoF}$ noted that the right to equal protection before the law prohibits any discrimination based on political opinion, religion etc.

The other landmark case that invokes international instruments is the Kedija Case. The case involved the constitutionality of adjudication by a religious court (Nai'ba court) on the basis of Sharia law against the consent of the applicant. Before its submission to the Council, appeal was lodged to the Supreme Sharia Court and finally to Cassation Division of the Federal Supreme Court. The applicant was assisted by the Ethiopian Women Lawyers Association (EWLA) in bringing the case to the CCI which provided its recommendation to the HoF stating that the right of the applicant was violated. It pointed that the applicant should have been allowed to express her consent before the case was entertained by a religious court. In this regard, the interpretation made by the HoF was based on the right guaranteed under the FDRE Constitution and international human rights instruments ratified by Ethiopia.

In Ato Wesen Alemu et. al vs. Amhara National Regional State Justice Professionals Training Institute (which involved denial of visually impaired experts from becoming a judge), the HoF indicated that such denial is against Articles 25 and 41(2) of the FDRE Constitution and the International Convention on the Rights of Persons with Disabilities. ${ }^{80}$ The $\mathrm{CCI} / \mathrm{HoF}$ in the above cases only cited the provisions of the Constitution and international human rights instruments. The decision did not elaborate the provisions using General Comments and international human rights jurisprudence on the issue. ${ }^{81}$

\subsection{Legislative intent}

In this approach, interpretation is made based on the intent of the legislator which can be inferred from the history of drafting and adopting the law. This

\footnotetext{
${ }^{80}$ Mustefa, supra note 59, p. 36.

${ }^{81}$ General Comments are issued by human rights treaty bodies interpreting treaty provisions. The core human rights instruments ICCPR, ICESCR, CRC, CEDAW, CRPEW, CAT, CERD, CED and ICRMWF have monitoring treaty bodies/Committees which interpret the treaty provisions by adopting General Comments.
} 
approach takes into account circumstances which gave rise to the adoption of the Constitution or legislation. ${ }^{82}$ Although the CCI and HoF have mentioned the purpose of a constitutional provision in most instances, they did not refer or cite the intent of the framers of the Constitution by referring to sources of legislative intent such as minutes documented during the drafting and approval processes of the Constitution. ${ }^{83}$ It is in very few cases that the CCI and HoF considered the intention of the legislator in reference to their interpretation of a certain legislative provision. ${ }^{84}$

\section{Implications of Lack of Principles/Methods of Interpretation on Human Rights}

$\mathrm{CCI} / \mathrm{HoF}$ has made decisions that have positive and negative implications on human rights. An overview of decisions that fall under both categories show the need for principles/ methods of interpretation, the absence of which has adverse implications on human rights.

\subsection{Decisions in tandem with human rights}

There are cases that have applied international human rights provisions and principles and fundamental rights incorporated in the FDRE Constitution such as the best interest of the child, right to appeal, access to justice. ${ }^{85}$ In Civil Servants Administrative Tribunal vs. FDRE Revenues and Customs Authority and its Moyale Branch Office, the CCI has (yet awaiting the final decision by $\mathrm{HoF}$ ) invalidated the power of the Director General of Ethiopian Revenues and Customs Authority to dismiss employees. ${ }^{86}$ This is indeed commendable.

This case was held constitutional in Ato Ashenafi Amare et al vs. the Ethiopian Revenues and Customs Authority (ERCA) that challenged the constitutionality of the provision in the regulation which prohibits judicial review of the decision of the Director General. Ato Ashenfi was dismissed from (ERCA) based on Regulation No. 155/2007 that allowed the General Director of the Customs and Revenue Authority to dismiss employees on the ground of

\footnotetext{
${ }^{82}$ Muthomi, supra note 61.

${ }^{83}$ Supra note 70.

${ }^{84}$ Ato Tatek Hailemariamet. al vs. Ato Ayele Habteselasie cited in Mustefa Nasser Hassen, supra note 59, p. 31.

${ }^{85}$ These cases include Melaku's case, Kedija case, Benshnguel case, W/ro Halima Mohamed v. Ato AdemAbdi, Ato Birhanu Regassa Urgi vs. MeskermMitiku; Emahoye G/Eyesus (SurafealZewdu's Mother) Case and Ato Wesen Alemu et. al vs. The Amhara National Regional State (ANRS) Justice Professionals Training Institute case.

${ }^{86}$ Civil Servants Administrative Tribunal v. FDRE Revenues and Customs Authority and its Moyale Branch Office, File No. 2189/09 (Tir 8, 2011 E.C. (2019)) (Copy of case on file with the author)
} 
corruption and disciplinary issues. According to the Regulation, such decision is not subject to any judicial review. However, the CCI indicated that the judiciary can be limited from judicial review by a Parliament in a Parliamentary form of government. It noted that the Regulation does not violate access to justice and the legislator has discretion to limit the justiciability of a case.

However, CCI has changed its interpretation in Civil Servants Administrative Tribunal vs. FDRE Revenues and Customs Authority and its Moyale Branch Office. The case was referred to CCI by the Civil Servant Tribunal challenging the constitutionality of the same Regulation which prohibits the judiciary from reviewing the decision of the Director General of Ethiopian Revenues and Customd Authority to dismiss an employee. The Tribunal requested CCI to evaluate the constitutionality of the provision of the Regulation in light of Articles 37(1) and 20(4) of the FDRE Constitution and Article 14(3)(b)(e) of the Covenant on Civil and Political Rights. These provisions provide access to justice and ensure the rights of accused persons to have access to any evidence against them, to adduce evidence in defence and to examine any witness against the accused. CCI held that the prohibition of judicial review on the decision of the Director General to dismiss an employee is contrary to the provisions of the Constitution and international human rights instruments. ${ }^{87}$ The inconsistency observed in the two decisions is, inter alia, related with lack of well-defined approaches/principles of interpretation.

\subsection{Decisions that depart from human rights principles}

There are cases which are not decided in tandem with human rights because of inconsistent approaches in interpretation. Most of these cases were rejected by CCI for lack of the need for constitutional interpretation although the cases should have been entertained by $\mathrm{CCI} / \mathrm{HoF}$. In a second case involving Melku Fenta, he was not allowed to benefit from a legal provision favourable to his case. Under the Customs Proclamation, which came into force after the accusation of Melaku Fenta $e t$ al in a corruption case, it is provided that some of the customs violations (the defendants were accused of) no longer carry criminal liability. This prompted the defence team to cite the constitutional principle of a more favourable law to apply in their case and sought constitutional interpretation. ${ }^{88}$ However, the case was dismissed by CCI as it does not involve constitutional interpretation.

In Negaso case, Proclamation No. 255/2001 (which denies a former president from getting benefits he used to get for participating in politics) was challenged and brought before CCI. Former President Dr. Negasso was denied to benefit from entitlements provided under the Proclamation for former presidents

\footnotetext{
${ }^{87}$ Ibid.

${ }^{88}$ Melaku's case, File no. 1421/07, Council of Constitutional Inquiry.
} 
because he participated as an independent candidate in an election. CCI held that the Proclamation does not contradict with the Constitution for prohibiting a former president from getting the benefits where he/she engages in political activities. ${ }^{89}$ In the CUD case $e^{90}$ indicated earlier, the Federal First Instance Court had requested whether the directive issued by the late Prime Minister after the 2005 elections restricting the right to assembly, demonstration and petition in Addis Ababa for a month is constitutional. The CCI in its brief decision rejected the cases stating that it does not involve constitutional interpretation since the Prime Minister is the highest executive vested with wide powers based on Articles 49, 72(1) and 74(13) of the FDRE Constitution.

Abdi Jibril argued that the decision erred by failing to distinguish between limitation and suspension of rights. The decision considered the restriction on the right to assembly, demonstration and petition as limitation. ${ }^{91}$ In another case involving the Anti-corruption Proclamation which denies the right to bail for all accused of corruption, the CCI held that the applicant's right to bail is not violated by the Proclamation. ${ }^{92}$ The trend of the CCI to reject cases after making a determination of whether there is a constitutional violation by interpreting constitutional provisions has indeed adversely affected the rights of the complainants. As the CCI is not a body that is entrusted to make final decision on constitutional interpretation, these cases should have been referred to HoF for final decision.

In light of the foregoing discussion, it can be concluded that CCI and $\mathrm{HoF}$ have rendered some decisions that have duly involved valid constitutional interpretation. However, consistent interpretation on similar issues is clearly lacking in politically sensitive cases as manifested in the CUD case, Melaku's case and Negaso's case. Such selective approaches of $\mathrm{CCI} / \mathrm{HoF}$ are nurtured and aggravated by the lack of principles/approaches of constitutional interpretation.

\section{Conclusion}

Lack of coherence and consistency in the decision of the CCI and HoF is attributable to lack of rules that provide guiding principles of constitutional interpretation. The failure of CCI and $\mathrm{HoF}$ in applying the correct constitutional interpretation method in evaluating the constitutionality of legislation has

${ }^{89}$ The case of the former FDRE President Negasso in House of Federation, Journal of Constitutional Decisions, 2009 E.C. (2017), Vol. 2 (2), p. 36-41.

${ }^{90}$ Coalition for Unity and Democracy vs. Prime Minister Meles Zenawi Asres, Fed. First Instance Ct., Lideta Div., File No. 54024 (Decision of 3 June 2005) (26 Ginbot 1997 E.C.)

91 Abdi Jibril Ali (2012), 'Distinguishing Limitation on Constitutional Rights from their Suspension: A Comment on the CUD Case', Haramaya Law Review, p. 2.

${ }^{92}$ Adem, supra note 11, p. 86. 
resulted in inconsistent decisions. The $\mathrm{CCI}$ and HoF have in most instances failed to apply the balancing and proportionality test. Lack of rules on constitutional interpretation is susceptible to discretionary patterns of interpretation driven by the political and personal whims rather than valid, consistent and predictable legal analysis.

Adem argues that the CCI and HoF have been "simplistic and unsystematic" in constitutional interpretation and he noted that "one can clearly see that the Council engages in justifying government action rather than reviewing it critically". ${ }^{93}$ Members of the HoF are regularly changed based on elections, and HoF meets only twice a year. Moreover, its size makes it "unsuited to follow a principled, coherent, reasoned and detailed approach to constitutional interpretation". ${ }^{94}$ Various scholars argue that the HoF which is political organ is unfit for constitutional interpretation because its members lack the qualification, expertise and experience in constitutional law and interpretation. Although the $\mathrm{CCI}$ is established to address this gap, the HoF has the final say on cases that involve constitutional interpretation and may not properly examine and analyse the recommendations of CCI and duly accept, vary or reject them based on their merit.

Furthermore, the CCI and HoF have frequently acted as adjudicatory bodies by going ultra vires and applying the constitutional provisions to questions of fact on cases referred to them for constitutional interpretation by courts. These tendencies of $\mathrm{CCI} / \mathrm{HoF}$ which are political organs adversely affect the separation of powers among the state institutions. It also affects the rights of citizens who should be exclusively adjudicated before an independent judiciary rather than a political organ. The alleviation of these challenges requires the formulation and adoption of rules of procedure and principles that guide constitutional interpretation. In the absence of such institutional schemes, CCI and HoF can find it difficult to render consistent, predictable and coherent decisions.

\footnotetext{
${ }^{93}$ Id., p. 88.

${ }^{94}$ Id., p. 89.
} 